\title{
Hvordan kan kommuner ivareta etterlatte ved selvmord?
}

Det er avgjørende å støtte etterlatte etter selvmord over år, ikke uker. Fredrikstad kommunes kriseteam har gode erfaringer med samarbeid mellom profesjonelle og frivillige hjelpere.

Gry L. Gavrel

Psykiatrisk sykepleier

Fredrikstad kommune

Psykososial krisestøtte

Kommunehelsetjeneste

Organisering

Psykisk helse

Sorg

Sykepleien 2020108 (82325) (e-82325)

DOI: 10.4220/Sykepleiens.2020.82325

\section{Hovedbudskap}

Etterlatte ved selvmord står i fare for å utvikle betydelige fysiske og psykiske helseplager og tidlig død. For de etterlatte vil krisereaksjonene og symptombelastningen være den samme som ved annen brå $\mathrm{d} \varnothing \mathrm{d}$, men i tillegg har de helt spesielle behov for psykososial støtte. Tilbakemeldinger fra etterlatte og fagfolk er at hjelpen er svært varierende fra kommune til kommune, og ikke alle som ønsker hjelp, blir tilbudt hjelp. Hva skal til for å møte etterlatte ved selvmord på en god måte?

En dag tidlig på sommeren $2020 \mathrm{kom}$ jeg som del av kommunens kriseteam inn i en bolig. En voksen hadde tatt livet sitt i hjemmet, og ifølge kona hadde han mistet både jobben og livsmotet i kjølvannet av koronakrisen. 
Hans egne to barn i tenårene hadde funnet faren sin død. Hva vil denne opplevelsen gjøre med disse barna? Hva kan vi bidra med? Hvordan skal vi jobbe best mulig i denne saken og $\mathrm{i}$ andre saker som likner?

Jeg ønsker med denne artikkelen å drøfte hvilke konsekvenser selvmord kan ha for etterlatte, og hvordan vi som profesjonelle kan bistå dem på best mulig måte. Særlig viktig er det å formidle brukerstemmen, altså tilbakemeldinger fra etterlatte om hvordan de ønsker å bli møtt og hjulpet.

Interessen for dette temaet har jeg fra mange års erfaring $\mathrm{i}$ jobben som psykiatrisk sykepleier i Fredrikstad kommunes kriseteam, hvor jeg ofte møter etterlatte etter selvmord.

Det siste året har jeg fått påfyll av nyere kunnskap om kriser, traumer og sorg som student på videreutdanningen «Krisehåndtering og traumebehandling» ved Universitetet i Troms $\varnothing$.

\section{Etterlatte trenger psykososial støtte}

Hvert år tar mange mennesker livet sitt i Norge. Statistikken fra 2018 viser 674 selvmord, og for hvert av disse estimeres det ti nære etterlatte og berørte. Det utgjør 6740 mennesker $(1-2)$.

For etterlatte ved selvmord vil krisereaksjonene og symptombelastningen være den samme som ved annen brå $\mathrm{d} \varnothing \mathrm{d}$, men i tillegg har de helt spesielle behov for psykososial st $\varnothing$ tte knyttet til at avd $\varnothing$ de selv valgte å ta livet sitt (2).

Barn som etterlatte er i en særstilling ved at de skal bære tapet lengst, det vil si resten av livet. Hvordan foreldrene mestrer situasjonen, har mye å si for hvordan barna vil få det (3).

En etterlatt datter på ti år sa dette til meg en gang: «Jeg er så lei meg, men jeg tør ikke vise mamma at jeg er lei meg, for jeg er redd for at hun skal bli enda mer lei seg, så jeg går inn på do og skriker inne i håndkleet.»

Mange etterlatte ved selvmord sliter med skyld, selvbebreidelser og skam i tillegg til sorgen. Det er også fremdeles knyttet en del stigmaer til selvmord (4). 
Edwin S. Shneidman, en av grunnleggerne av moderne suicidologi, beskriver etterlattes situasjon slik: «The person who commits suicide puts his psychological skeleton in the survivor's emotional closet.» (5, s. 38)

\section{Krisereaksjoner må tas på alvor}

Krisereaksjoner, lengsel og savn er normale reaksjoner på et tap og bør ikke sykeliggjøres. De vil vanligvis gå over av seg selv. Sorg og kriser kan også føre til alvorlige psykiske og fysiske helseplager.

Sørgende har høyere dødelighet, høyere hyppighet av uførhet samt høyere forekomst av medisinbruk og sykehusinnleggelser enn ikke-sørgende (6).

Sørgende har også $\varnothing$ kt selvmordsrisiko. Hos sørgende som de siste to årene har mistet foreldre eller ektefelle, er selvmordsraten fem ganger så stor som i resten av befolkningen (3).

\section{三 «Sørgende har også økt selvmordsrisiko.»}

Barn som har mistet foreldre eller søsken, har mer helseproblemer og $\varnothing \mathrm{kt}$ selvmordsrisiko (7). Vi som jobber med mennesker i krise, bør ha kunnskaper om sorg og sorgbehandling og vite når og hvor vi skal henvise om sorgen blir langvarig eller komplisert.

Tidligere fasetenkning, at sorgen følger faste faser, er erstattet av ny kunnskap. «Tospor-modellen», utviklet av Margareth Stroebe og Henk Schut, ser sorgen som en prosess der de som sørger, veksler mellom å ha søkelyset på det som er tapt, men retter samtidig blikket fremover for å gå videre i livet (6).

Denne kunnskapen får konsekvenser for hvordan vi møter sørgende. Forskning på sorg og sorgbehandling er et relativt nytt felt og er ifølge Atle Dyregrov et «stebarn» til traumeforskningen (8). Suicidologien er også en nyere vitenskap, der forskning på etterlatte har vært det minst utviklede området til nå (5).

\section{Hvem er de etterlatte?}


Tidligere ble etterlatte brukt om den nærmeste familien, men i dag er det mer nyansert, og etterlatte blir brukt om en større krets. I tillegg til de nærmeste pårørende kan det dreie seg om andre i familien, venner, kjærester, medstudenter, arbeidskolleger og alle som opplever å ha nære bånd til avd $\varnothing$ de.

Tidligere besto kjernefamilien av mor, far og barn, mens i dag er det vanlig at det etableres nye familier, ofte med nye barn. Familiekonstellasjoner kan være komplekse og kompliserte. Fra praksis ser vi at når vi reiser på et kriseoppdrag, avdekker vi ofte nye deler av nettverket som også har behov for hjelp.

Ved å tegne nettverkskart får vi en bedre oversikt. Om en elev på en skole tar livet sitt, vil mange medelever og lærere være svært berørt, og mange ønsker å få snakke med en profesjonell. Men også medpasienter og profesjonelle regnes som etterlatte hvis avd $\varnothing$ de var under behandling.

Når en pasient eller en klient tar livet sitt, blir de som følger opp vedkommende, ofte sterkt følelsesmessig berørt. De profesjonelle har liknende reaksjoner på selvmord som andre etterlatte, men kan i tillegg bli utsatt for formell gransking av Helsetilsynet og syndebukkprosesser på arbeidsplassen (5).

I masteroppgaven til Anne-Lill Haddeland, leder for selvmordsforebyggende team ved Regionalt ressurssenter om vold, traumatisk stress og selvmordsforebygging (RVTS) Sør, er et av funnene at når barnevernskuratorer mister en klient $\mathrm{i}$ selvmord, vurderer mange å slutte i jobben (9).

\section{«Postvention» er «prevention»}

«Postvention» er et begrep som er relativt nytt og betegner alle tiltak som kan redusere de negative følgene selvmord kan ha for de etterlatte (2). Viktigheten av forebygging, eller «prevention», av selvmord er allment akseptert, og det har vært og er fortsatt stor oppmerksomhet på å identifisere årsakene til at mennesker tar sitt liv.

Disse funnene blir brukt til å kartlegge selvmordsrisiko. Det har vært mindre oppmerksomhet på konsekvensene selvmordet har for de etterlatte. Nyere forskning har tydeliggjort at etterlatte har forhøyet risiko for selv å ta sitt eget liv (7). 
Selvmord i nære relasjoner er altså en viktig identifisert årsak til selvmord. Ergo kan det være selvmordsforebyggende å bistå etterlatte etter selvmord. I et slikt perspektiv blir det viktig å lære mest mulig om hvordan bistanden kan ytes best mulig - og å omsette kunnskapen i praksis.

\section{Kommuner gir ulik krisestøtte}

Det er kommunens ansvar å yte hjelp til etterlatte ved selvmord samt å bistå mennesker i krise. Veilederen «Etter selvmordet - Veileder om ivaretakelse av etterlatte ved selvmord» gir råd og anbefalinger om hvordan hjelpen bør være, men det er opp til enhver kommune å organisere hjelpen (2).

Krisestøtte har til hensikt å normalisere reaksjoner, mobilisere nettverk og bidra til egenmestring (10). Det anbefales at alle kommuner har psykososiale kriseteam for å gi psykososial omsorg og støtte ved kriser, ulykker og katastrofer (2).

Tilbakemeldinger fra etterlatte og fagfolk er at hjelpen fremdeles er svært varierende fra kommune til kommune, og ikke alle som har behov for hjelp, blir tilbudt hjelp. Hva som defineres som en krise, er også forskjellig fra kommune til kommune.

Selv om veiledere og litteratur definerer selvmord som en krise, er det noen kommuner som anser selvmord som en personlig tragedie, og som ikke aktiverer kriseteamet fordi de mener det faller utenfor deres funksjon (11).

\section{$\equiv$ «Ikke alle som har behov for hjelp, blir tilbudt hjelp.»}

Gry Lunde fra LEVE, Landsforeningen for etterlatte ved selvmord, uttalte til VG Nett i forbindelse med at veilederen ble utgitt, at hun var positiv til veilederen, men $\varnothing$ nsket at den var mer forpliktende. Hun ønsket også at kommunene fikk pålegg, ikke bare råd og anbefalinger (12).

Etter et selvmord vil det være mange aktører involvert, og det er viktig å sikre gode rutiner for overføring av informasjon og flyt slik at hjelpen ikke stopper opp. Hjelpen bør koordineres på et høyere nivå. 
Skoler, barnehager og fastleger er alle viktige deler av kriseoppfølgingen. Når krisen har lagt seg, kan man kople på frivilligheten og likemannsst $\varnothing t t e$. Som en del av kriseteamet ser jeg hvor viktig det er for de etterlatte med samarbeid på tvers, slik at de blir ivaretatt på alle arenaer.

\section{Hjelpen må være proaktiv}

Det som går igjen av tilbakemeldinger fra etterlatte i litteratur og artikler som omhandler etterlatte ved selvmord, er at de ikke er i stand til å oppsøke hjelp selv når de er i krisesituasjonen. De ønsker at hjelpen kommer til dem (13).

Når man vet at vanlige reaksjoner ved en krise er sjokk, nummenhet, tankekaos, tilbaketrekking og en følelse av uvirkelighet, forstår man at det er vanskelig eller umulig selv

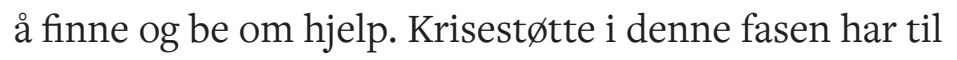
hensikt å skape trygghet og dempe uro.

Forskning viser at etterlatte får mindre posttraumatiske plager hvis de får hjelp tidlig til å dempe uro (10). Det anbefales at hjelpen er proaktiv, det vil si at hjelpeapparatet aktivt tar kontakt med kriserammede, og at de tar kontakt på nytt hvis den rammede takker nei til hjelp første gang. Det holder ikke å gi telefonnummeret og be etterlatte ringe ved behov (13).

Umiddelbart etter et selvmord opplever kriseteamet at etterlatte ofte trenger praktisk hjelp i tillegg til krisestøtte. De kan være bekymret for økonomien, hvordan de skal klare å betale for begravelsen eller andre regninger.

De kan ha problemer med å håndtere sosiale medier og kan trenge hjelp til å kontakte begravelsesbyrå, skole og arbeidsplass. Mange kvier seg også for å dra tilbake til hjemmet hvis selvmordet skjedde der.

I veilederen for etterlatte ved selvmord anbefales det at politiet har et system for å rekvirere hjelp til rengjøring og rydding, men vår erfaring er at dette ikke alltid skjer. Det oppleves som traumatisk for etterlatte å måtte rydde og vaske etter et selvmord.

Jeg var selv ute på et kriseoppdrag en gang hvor barna satt i sofaen mens mor vasket blod etter at far hadde skutt seg i hjemmet. Sansene er aktivert i en stressituasjon, og syn, lukt og lyder kan være noe de etterlatte kan slite med lenge. A klargjøre boligen og legge til rette for at etterlatte kan komme hjem igjen, er en viktig del av jobben vår. 


\section{Etterlatte ønsker hjelp over tid}

En 13 år gammel gutt jeg snakket med etter at moren hadde tatt livet sitt, spurte om han brukte opp hjelpen hvis vi kom to dager på rad.

Tidligere hadde vi rutiner på at kriseoppfølgingen skulle bestå av én til fem samtaler, og ved behov ville vi bistå de etterlatte med å søke om hjelp via det ordinære hjelpeapparatet. I dag, basert på egen erfaring og oppdatert kunnskap, vet vi at etterlatte har behov for st $\varnothing$ tte mye lenger.

\section{$\equiv$ «Allerede etter begravelsen opplever etterlatte at de får mindre oppmerksomhet fra omgivelsene.»}

Familie og venner mobiliseres i en krise, og mange synes det er godt med all støtten de får i begynnelsen. Men etter hvert avtar interessen, andre går videre, og det forventes at de etterlatte også gjør det. Allerede etter begravelsen opplever etterlatte at de får mindre oppmerksomhet fra omgivelsene.

Tilbakemeldinger fra etterlatte viser at de opplever det som godt at kriseteamet har kontakt over tid. En telefon før høytider eller bursdager kan utgjøre en forskjell.

Ved å følge opp etterlatte over tid får vi også anledning til å observere om sorgen forløper normalt, eller om de etterlatte behøver mer hjelp. Da kan kriseteamet kople på andre aktører som kan bistå de etterlatte i sorgarbeidet.

I sin masteroppgave «Mitt hjerte er ikke helt, det er halvt» har Eva Olsen studert etterlatte ved selvmord, deres opplevelse av selvmordet og erfaringer de har med hjelpeapparatet i etterkant.

Hennes funn viser at etterlate ved selvmord ikke fikk den hjelpen de hadde $\varnothing$ nsket seg, og de etterlyste mer anerkjennelse, forståelse og omsorg fra skole, sosialt nettverk og kommunalt hjelpeapparat (4).

\section{Vi samarbeider med frivillige organisasjoner}


Fredrikstad ble kåret til årets pårørendekommune i 2019. Vesentlig for tildelingen var kommunenes pårørendesenter. Spesialkonsulent Leif Nybøle ved senteret leder det lokale prosjektet «Sammen om sorg». De ønsker å øke samhandlingen mellom ressursene som finnes, både innenfor tjenesteapparatet og i det frivillige.

Nybøle har også meldt inn et behov for felles prosedyrer for å ivareta etterlatte ved selvmord og narkotikarelatert $\mathrm{d} \varnothing \mathrm{d}$. Dette lokale prosjektet har blitt knyttet opp til det nasjonale END-prosjektet, som er et forskningsprosjekt ledet av Kari Dyregrov. De skal unders $\varnothing$ ke hvordan etterlatte ved narkotikarelaterte dødsfall har det fysisk, psykisk, eksistensielt og sosialt.

Pårørendesenteret er et godt sted for etterlatte å dele tanker og erfaringer og sortere kaos. Pårørendegrupper tilrettelegger og stimulerer til normal sorgbearbeidelse og har et nettverk av personer med egne erfaringer som har en helt spesiell verdi for etterlatte.

\section{God ledelse er avgjørende}

Samme hvor kunnskapsrike og erfarne de ansatte i et kriseteam er, så er det avgjørende at ledelsen har klare mål for kvaliteten på tjenesten. En god ledelse må arbeide ut fra ressurser og økonomi, men som 22. juli-kommisjonen skriver i sin rapport, «[...] så teller ressurser, men bruken avgjør» (14).

\section{三 «Når en krise oppstår, må vi skyve på planlagte gjøremål.»}

De som skal arbeide med kriser, må få faglig påfyll jevnlig, og tjenesten må organiseres slik at medlemmene får mengdetrening ved at de deltar på kriseoppdrag med jevne mellomrom. Alle som jobber i kriseteam, har også andre oppgaver.

Det betyr at når en krise oppstår, må vi skyve på planlagte gjøremål. Det krever god ledelse å hjelpe de ansatte til å vekte hva som er viktigst i slike situasjoner. Ofte medfører krisehåndtering belastninger på kolleger som må steppe inn. Det er et lederansvar å fordele oppgavene og skape forståelse hos alle som blir berørt. 


\section{Konklusjon}

Mye oppdatert kunnskap om kriseoppfølging og sorg kommer fra hendelsene 22. juli. Både 22. juli-kommisjonens rapport og Helsetilsynets kartlegginger viser at befolkningen får ulik hjelp, avhengig av hvor de bor. Kommunene har rustet seg siden rapporten ble utgitt, og det er håp om at tilbudet i dag er mye bedre.

I innledningen på denne artikkelen startet jeg med å beskrive en fiktiv hendelse. Den likner veldig på situasjoner vi i kriseteamet ofte møter. Jeg stilte spørsmål om hvordan vi skal jobbe best mulig i en sånn sak og i saker som likner.

Jeg vil hevde at vi nå tenker og jobber på en helt annen måte $\mathrm{i}$ Fredrikstad kommune når det gjelder etterlatte ved selvmord enn vi gjorde for bare to år siden. Vi er nå bedre forberedt når krisen inntreffer, og tenker langt mer planmessig på langsiktig ivaretakelse.

Basert på forskning og egne erfaringer har jeg fors $\varnothing \mathrm{kt}$ å dokumentere at det er helt avgjørende å støtte etterlatte etter selvmord over år, ikke uker.

Jeg har også fors $\varnothing \mathrm{kt}$ å vise hvor viktig det er med et godt samarbeid mellom profesjonelle og frivillige. Hvis vi får alt dette til å fungere, tror jeg at vi kan hjelpe langt flere etterlatte til et bedre liv, og at vi på sikt kan håpe på å se resultater i selvmordsstatistikken.

\section{Referanser}

1. Folkehelseinstituttet. Dødsårsaksregisteret. Selvmord etter kjønn, alder og dødsmåte. Tilgjengelig fra:

http://statistikkbank.fhi.no/dar/ (nedlastet 01.06.2020).

2. Helsedirektoratet. Etter selvmordet - Veileder om ivaretakelse av etterlatte ved selvmord. Oslo; Helsedirektoratet; 2011. IS-1898.

3. Bugge KE, Eriksen H, Sandvik O. Sorg. 3. utg. Bergen: Fagbokforlaget; 2011.

4. Olsen E. Mitt hjerte er ikke helt, det er halvt. En kvalitativ unders $\varnothing$ kelse av hvordan etterlatte blir ivaretatt av hjelpeapparatet etter et selvmord i nær familie. (Masteroppgave.) Halden: Høgskolen i Østfold, Avdeling for helse og sosialfag; 2016. 
5. Larsen K. Bokanmeldelse: Postvention in action. The international handbook of suicide bereavement support.

Suicidologi. 2018;3:38-40.

6. Stroebe M, Stroebe W, Schut HAW. Helsemessige følger av sorg. Tidsskrift for Norsk psykologforening. 2011;48:88397.

7. Dyregrov A, Dyregrov K, Kristensen P. Hva vet vi om sorg og komplisert sorg? Psykologisk.no. 26.09.2014. Tilgjengelig fra: https://psykologisk.no/2014/o9/hva-vet-viom-sorg-og-komplisert-sorg/ (nedlastet 01.09.2020).

8. Feyn S. Sorgen er blitt et stebarn. Dagsavisen. 09.07.2014. Tilgjengelig fra: https://www.dagsavisen.no/nyheter/innenriks/sorgen-er-blittet-stebarn-1.285598 (nedlastet 01.06.2020).

9. Haddeland A. Selvmord som tema for kurator i barnevernstjenesten. Hvordan påvirkes kurators arbeidssituasjon når en klient tar sitt liv? (Masteroppgave.) Oslo: Universitetet i Oslo, Institutt for klinisk medisin; 2012.

10. Helsedirektoratet. Mestring, samhørighet og håp. Veileder for psykososiale tiltak ved kriser, ulykker og katastrofer. Oslo: Helsedirektoratet; 2016. IS-2428.

11. Hoel TL. Toppmøte 2017: Etterlatte ved selvmord har store utfordringer. Erfaringskompetanse.no. 27.04.2017.

Tilgjengelig fra:

https://erfaringskompetanse.no/toppmote/toppmote-2017etterlatte-selvmord-store-utfordringer/ https://erfaringskompetanse.no/toppmote/toppmote-2017etterlatte-selvmord-store-utfordringer/ (nedlastet 15.03.2020).

12. Nilssen D, Svendsen SH. Mener etterlatte ikke får god nok oppfølging etter selvmord. VG.no. 14.07.2012. Tilgjengelig fra: https://www.vg.no/forbruker/helse/i/xLxoX/meneretterlatte-ikke-faar-ikke-god-nok-oppfoelging-etter-selvmord (nedlastet 30.03.2020).

13. Dyregrov K. Hvilken hjelp $\varnothing$ nsker etterlatte ved selvmord? Suicidologi. 2004;9:8-11.

14. NOU 2012: 14. Rapport fra 22. juli-kommisjonen. Oslo: Departementets servicesenter, Informasjonsforvaltning; 2012. 
